\title{
Business Continuity Management in a Time of Crisis: Emerging Trends for Commercial Banks in Zimbabwe during and Post the Covid-19 Global Crisis
}

\author{
Taurai Muparadzi ${ }^{1}$, Letwin Rodze $^{2}$ \\ ${ }^{1}$ Department of Governance and Public Management, University of Zimbabwe, Harare, Zimbabwe \\ ${ }^{2}$ Treasury Operations Department, First Capital Bank, Harare, Zimbabwe \\ Email: tauraimuparadzi@gmail.com, letwin.rodze@firstcapitalbank.co.zw
}

How to cite this paper: Muparadzi, T., \& Rodze, L. (2021). Business Continuity Management in a Time of Crisis: Emerging Trends for Commercial Banks in Zimbabwe during and Post the Covid-19 Global Crisis. Open Journal of Business and Management, 9, 1169-1197.

https://doi.org/10.4236/ojbm.2021.93063

Received: January 12, 2021

Accepted: May 18, 2021

Published: May 21, 2021

Copyright $\odot 2021$ by author(s) and Scientific Research Publishing Inc. This work is licensed under the Creative Commons Attribution International License (CC BY 4.0).

http://creativecommons.org/licenses/by/4.0/

\begin{abstract}
Covid-19 has presented severe and increasingly complicated challenges which confront the very survival of banks in Zimbabwe. The urgency and relevance of business continuity management (BCM) to alleviate potential risks and quicken recovery remain important. While there is proliferation of literature on the impact of Covid-19 on businesses across the globe, there is little known about BCM strategies among Zimbabwean banks under Covid-19 conditions. This paper focuses on emerging trends in BCM approaches in the commercial banking sector in Zimbabwe and seeks to establish if existing BCM models provide an adequate response to the risks posed by the Covid-19 pandemic, establish strategies adopted by commercial banks in Zimbabwe to ensure an adequate response to the impact of the Covid-19 pandemic and to establish the likely implications of these strategies on the future of BCM in Zimbabwean commercial banks. Using a qualitative research approach, this paper concluded that existing BCM models among banks in Zimbabwe are not sufficient and are changing towards building permanent models with capacity to anticipate "surprises".
\end{abstract}

\section{Keywords}

Business Continuity Management, Business Recovery, Covid-19, Business Customer Loyalty, Pricing Strategies, Channel Integration

\section{Introduction and Study Context}

Business continuity management (BCM) has been extensively covered in litera- 
ture but there is a gap on literature related to BCM strategies by Zimbabwean banks during the Covid-19 crisis period. Business disruptions induced by Covid-19 have detrimental effects on organizations and there are numerous responses to Covid-19 induced challenges among banks in Zimbabwe. Little is however known about strategies and decision making for disaster-caused business continuity management among banks in Zimbabwe. Building on the strategic importance of $\mathrm{BCM}$, this paper addresses that gap by analyzing $\mathrm{BCM}$ strategies adopted by banks in Zimbabwe in the context of the Covid-19 crisis.

BCM cuts across all sectors of the economy, but the main focus of this paper is the banking sector in Zimbabwe. The banking sector is located at the nerve center of any economy and the potential for disruptions generates shocks at the individual bank level that can severely shake the entire financial system and economy of a country. Across the globe, central banks have attracted attention in analyses on national responses to the covid-19 pandemic. In Zimbabwe in particular, the Reserve Bank of Zimbabwe increased its support to the productive sector from ZWD1 billion to ZWD2.5 billion, reduced the statutory reserve requirement from $5 \%$ to $4.5 \%$, reduced the Bank Policy rate from $35 \%$ to $15 \%$, fixed the ZWD exchange rate to the US dollar at USD1:ZWD25.00 before reintroducing the auction rate, abolished compulsory liquidation for exporters and introduced Corporate Bills as an Open Market strategy to stabilize the exchange rate and market prices (RBZ, 2020) among other strategies. This cocktail of measures lays bare the fact that the banking operating environment is vulnerable to induced change and surprise directives. The reality is that businesses across the globe face serious socio-economic predicaments due to Covid-19 and the quicker companies can respond to the pandemic situation the more likely their chances of survival (Asare et al., 2020). This is evidence that BCM approaches modelled before the outbreak of the Covid-19 pandemic are undergoing drastic and surgical remodeling to enable them to adequately respond to the demands of an operating environment populated by Covid-19 pandemic trepidations. In fact, significant changes have to be made to business operations with some level of urgency. Research by Abu Bakar et al. (2015) shows that organizations with a higher commitment to BCM enhance their business resilience. Likewise, Sawalha (2013) notes that BCM helps improve organizational performance for organizations facing performance difficulties. This paper outlines some practical BCM strategies adopted by Zimbabwean banks in response to the Covid-19 pandemic. The paper is divided into sections which cover key segments of the study. Section 1 is the introduction and study context, section 2 explains BCM as a concept, Section 3 outlines the study methodology used, Section 4 summarizes main contributions from literature on $\mathrm{BCM}$, Section 5 presents the findings of the study and the final section is the conclusion and recommendation for further research. This study is expected to benefit banks by helping them to improve their BCM approaches during the Covid-19 pandemic and strengthen their preparation for similar future business disruptions. 


\section{BCM as a Concept}

Business Continuity Management (BCM) has its roots in disaster recovery planning and over time it has evolved to become a strategic management concern (Elliott et al., 2010). The roots of BCM are much older now and are embedded in the management of most organizations. Organizations now need to detect change in their operating environments and take action. Man-made and natural disasters trigger business interruptions for all types of organizations and such disruptions are accompanied by loss of human lives and business collapse or failure and often high private and social costs (De Mel, McKenzie, \& Woodruff, 2011; Banica, Kourtit, \& Nijkamp, 2020). Organizations in all sectors of the economy cannot trivialize the probable impact of such risky events. The need to build BCM capabilities that support business resilience and quicken business recovery from the impact of both foreseen and unforeseen disasters which affect both national economies and individual organizations is not in doubt. Learning from Elliott et al. (2010), concomitant changes to organizational processes, systems, business operations and future operating environments should be expected.

BCM has been variously defined in literature and this definitional diversity reveals the influence of various disciplines. According to Elliott et al. (2010), BCM is a holistic management process that identifies potential impacts that threaten an organization and provides a framework for building resilience and the capability of an effective response that safeguards the interests of its key stakeholders, reputation, brand and value creating activities. A closely related definition by Estall (2012) states that "BCM is a holistic management process that identifies potential threats to an organization and the impacts to business operations those threats, if realized, might cause and which provides a framework for building resilience and the capability of an effective response that safeguards the interests of its key stakeholders, reputation, brand and value creating activities." Pingel et al. (2012) also define business continuity management as the capacity of an organization to plan for and respond to incidents or events that impact or disrupt business operations pertaining to the coordination or repair, replacement of alternate locations or critical facilities or the reassignment of critical tasks based on staff availability. Heng (2007) further views BCM as a holistic management process to identify potential impacts from threats and develop response plans with the objective of increasing the organization's resilience to business disruptions and to minimize the impact of such disruptions. BCM thus plays the role of abating the debilitating impact of disasters on the various business processes.

A synthesis of the definitions above reveals fundamental elements of BCM. Firstly, BCM is a component of strategic management in modern organizations which focuses on the organization as a whole. Secondly, BCM's main concern is identifying potential threats emanating from disasters and building some level of resilience in advance to enable the organization to navigate the crisis period with 
minimal difficulty. Thirdly, it is anchored on sound planning and examination of alternative strategies for dealing with potential outcomes of disasters. In fact, the business continuity planning process involves a series of activities. Fourthly, $\mathrm{BCM}$ is a risk management approach that seeks to give all stakeholders confidence that the organization will survive in the event of a disaster. Lastly, BCM is rooted in crisis management, and it emphasizes service continuity. Given this analysis, BCM can therefore be defined as a strategic and holistic management process based on risk management approaches, that identifies threats to the organization as a whole which arises from natural or man-made disasters and provides alternative responses to the impact of such disasters that will enable organizations to effectively deal with a crisis with minimum disruptions to critical operations of the organization.

\section{Study Methodology}

A qualitative approach was adopted in this study. Desk research was used to obtain secondary data while primary data was obtained using email interviews and telephone interviews. Secondary data sources used include online books and journal articles focusing on BCM and disaster recovery literature and these were accessed through key word searches. A purposive sampling approach was used to select participants in their individual capacity from thirteen commercial banks in Zimbabwe. Out of the thirteen targeted BCM managers or officers, from the thirteen commercial banks, only seven participated in the study representing a $53.8 \%$ response rate which we considered sufficient to meet the objectives of the study. The following questions were asked: 1) What would you say are the implications of the Covid-19 pandemic on banking operations in Zimbabwe? 2) How would you describe the Business Continuity Management (BCM) model your bank had in place before the global spread of Covid-19 in terms of its key features and focus areas. 3) Would you certify the BCM model you had in place before the Covid-19 pandemic as fit to overcome the challenges brought about by the pandemic? 4. Do you also think that the Covid-19 pandemic exposed obvious gaps in your existing BCM plan and if so how? 5) What changes, if any, were made to your BCM model in order to cope with the impact of the Covid-19 pandemic? 6) Would you say these changes are temporary or will remain in place after the Covid-19 pandemic? A table of these questions was created on Microsoft excel and all responses to the questions were recorded against each question. Emerging patterns in these responses were identified through common words or phrases and the findings were compared with existing BCM theory. Conclusions were then made on the basis of dominant themes emerging from the data analysis.

\section{Literature Review}

Businesses operate in a very complex environment where change is constant but sometimes disruptive and a nightmare for some organizations. This under- 
standing elevates the prominence of $\mathrm{BCM}$ at the strategic importance level (Elliott et al., 2010). BCM processes are closely associated with ensuring that organizations can quickly recover from interruptions of strategic operations without exacerbating the impact of the interruption. As pointed out by Graham and Kay (2006), in any disaster, the focus of all stakeholders is on whether the organization will survive. Implied is that BCM requires a multi-lenses approach and should not be pushed aside as unimportant.

Pingel et al. (2012) study incidents or events that disrupt normal business operations and conclude that these will always be there and require a planned, trained, and exercised organizational resilience program that can re-establish critical business operations and minimize the impact of adverse incidents. Krell (2006) acknowledges that disasters of any nature act as gruesome wakeup calls to managers responsible for preparing their organizations to respond to disasters. The frequency, nature and impacts of disasters on organizations continue to change. Implied is that an emergency and disaster recovery plan is a requirement for most organizations. The basic response is in most cases the establishment of a generic crisis response center adapted to the size of the organization. Referring to Pingel et al. (2012), disaster recovery plans need continual improvement and must be supported by an elaborate organizational resilience program fit for effective business continuity in a time of crisis. This program should be anchored on a policy of risk prevention, preparedness, and mitigation at the strategic management level of the organization. Similarly, Khanna (2008) writes that continual testing and reevaluation of systems is necessary to any business continuity plan. Clearly this directs attention to the important aspects of effective BCM.

\subsection{Business Continuity Management Models}

The Split Operations Model and the Plan-Do-Check-Act Model for BCM BCM has followed an evolutionary path since the 1980s. Several predominant debates have emerged, with each exhibiting the key aspects of BCM in different paradigms and the result has been a number of models. Ayadi (2019) notes that banks adopt different business models with varying risk behaviors and by extension these bank business models have different BCM approaches. Understanding the way a bank's business model would respond to shock is important in order to choose the appropriate BCM model. The split operations model is one common model among banks and has potential for Zimbabwean banks. This model requires banks to disperse their systems and personnel in different locations, with each territory fully equipped to pick up operations real time at any time. This model is also known as the active/active model as it allows one territory to absorb the operational needs of another instantly in the case of a disaster (Khanna, 2008). The major credit for this model is that it reduces vulnerabilities related to concentrated operations. The major limitation, however, is that BCM costs are high. In Zimbabwe for example, most head office staff and branch staff for most banks are concentrated in one place. Learning from this model, the 
need to disperse operations is a central consideration for banks in Zimbabwe.

The Plan-Do-Check-Act Model according to Clark (2015) is a model that involves planning. The planning process takes into consideration the need to establish BCM policies, objectives, targets, processes and procedures relevant to the business model and ideal for delivering disaster recovery in times of crisis. The model also involves the implementation and operationalization of the BCM policies, controls, procedures and processes. After implementation, the BCM model is monitored and reviewed against set policies and targets and corrective or remedial action is then taken to improve the BCM model. Finally, management has to maintain and improve the BCM model based on the results of the remediation and improvement processes. This model clearly proposes a logical approach to BCM in organizations. Learning from this model, it is not far-fetched to recommend that banks in Zimbabwe need to adopt a step-by-step approach to BCM that guarantees continued improvement of existing BCM models. A model that combines aspects of these two models is however considered ideal for banks in Zimbabwe.

\subsection{Critical Requirements for Effective Business Continuity Management}

As stated above, a crisis response plan must be in place and should be ready to be activated to become effective immediately upon the occurrence of an incident that affects the organization's operations. Effective BCM should be practiced as suggested by Elliott et al. (2010). Clark (2015) uses the analogue of practicing to find a candle and match box by switching off the lights and checking if one can locate them as part of preparations for an emergency power outage that may occur in his emphasis of the need for organizations to practice BCM. Pingel et al. (2012) direct attention to the need to analyze each business activity and identify weaknesses that must be flashed out in order to reduce their impact on key aspects of the organization's operations. In addition, vital processes should be documented and staff training on these essential processes should ensure that more than one individual can perform them. An attendant and important consideration is that the crisis response plan must be capable of communicating important responsibilities of the essential staff during a crisis and all possible process alterations necessary to keep the organization's operations on course.

Pingel et al. (2012) also argue that organizations need to gather as much data or information about the incident as is possible that must be subjected to intense analysis in order to establish the potential impact on business operations. Likewise, Asare et al. (2020) emphasize that data analytics is crucial for assisting managers to make resilient decisions in crisis times. In that regard, Myers (2006) accepts that this helps the organization to define the problem. Implied is that the types of risks, the scope and scale of the threat posed by the risks need to be identified. This permits organizations to develop possible actions to address the effects of the disruption or to prevent further negative effects of the incident, re- 
spect the safety of individuals, keep all stakeholders updated and escalate requests for assistance or interventions where necessary. This resonates with Elliott et al.'s (2010) assertion that what is "crucial to the effectiveness of a BCM capability is the cooperation and coordination of resources that may reside in diverse locations within the organization." It is clear from these observations that coordination and cooperation in the configuration of resources create a recovery advantage though the central motif is that effective BCM is context dependent.

Compliance with laws and regulations is another critical requirement for effective BCM. Laws and regulations in both crisis and non-crisis time act as an important stimuli for BCM and they influence and enforce desired behavior that helps organizations respond and recover from disaster induced interruptions through compulsion. Kruskal et al. (2021) write that understanding state laws issued in response to the Covid-19 pandemic is a crucial ingredient for an effective response to the impact of the pandemic. Khanna (2008) also points out that governments encourage BCM because they are keenly aware of the impact disruptions in financial markets have on national economies and the global economy. Using the same line of reasoning, Elliott et al. (2010) underline that managers should be aware of the legal and regulatory issues that influence BCM as laws are a major driver of business continuity. By extension, laws and regulations are the control systems. Furthermore, Clark (2015) advises that organizations need to pay due deference to appropriate legislation and regulations applicable in their sector and compliance should be validated. Organizations should therefore understand the source, type, purpose, and appropriateness of domestic, sectoral and international regulations and how these affect responses to events which negatively affect the organization's operations. The possibility of regulations evolving during a crisis should also be taken into consideration. The prospect of organizations participating in the formulation of the regulations and attempting to shape them also merits consideration. Clearly, laws and regulations initiate, enforce and control BCM in times of crisis.

An organization's ICT posture is also an important determinant of the effectiveness of a BCM response in a time of crisis. As posited by Elliott et al. (2010), ICT or digital resilience is a critical disaster recovery pillar. Breznitz and Zysman (2013) note that ICT tools make bank employees more productive since most of the core banking processes involve human mediation. Similarly, Myers (2006) underlines that financial services organizations cannot operate for a day or two without computer processing. Inspired by the above findings, our study notes that Covid-19 pandemic lays bare ICT gaps and ICT potential respectively across many sectors in Zimbabwe. Muraleedharan (2014) and Gup (2003), underline that dramatic changes due to ICT have long provided banking flexibility for customers and operational agility for bank employees. In fact, ICT has potential to spearhead effective BCM during disaster induced interruptions. The development of new technology solutions that never existed before aids BCM res- 
ponses in a crisis as organizations build effective e-continuity measures to protect and sustain their essential operations. The old off-site brick and mortar BCM sites common among most Zimbabwean banks will be decomposed by the Covid-19 pandemic. Given this reality, it is not far-fetched to reason that effective BCM in times of crisis should look beyond traditional approaches.

Another vital precondition for effective BCM is a clear understanding of all the organization's activities, products and resource requirements of the organization. Clark (2015) argues that organizations can achieve this through ensuring that the BCM plan is rehearsed. Referring to Pingel et al. (2012), effective business continuity management should rely on business impact analysis data that identifies vital resources, a risk assessment or vulnerability assessment that identifies internal and external threats to critical activities, and a clear strategy that identifies dependencies with all stakeholders. There is need for BCM managers to direct attention to the resources that contribute to each activity and product. Elliott et al. (2010) suggest that resources leading to the production of a final product should be identified. Banks for example offering international payment and internet banking services will depend mostly on IT and communication equipment. The continuity of international payment and internet baking services will thus largely depend on availability of these resources. Understanding resource and product dependencies is also critical as interruptions in one part of the network may potentially affect all operational activities. It is appropriate at this stage to point out that banks will therefore need to upgrade their infrastructure to be more resilient to unforeseen disasters post the Covid-19 pandemic.

Effective BCM for the banking sector also requires an industry level model that protects shared systems and infrastructure. This robust approach to BCM flushes out vulnerabilities that threaten the banking sector as a whole. Borrowing words from Ojansivu and Medlin (2018) there is need "for shared, mutual interest and collective action" towards developing a banking sector specific BCM model. Banking history is littered with examples of disasters that shook the industry as a whole to its core. As a result, Khanna (2008) suggests that it is important for the banking sector to protect intricately linked systems particularly in a straight through processing (STP) environment. Based on Khanna's (2008) and Ojansivu and Medlin's (2018) suggestions, our study relates that to clearing and settlement systems such as the Real Time Gross Settlement System (RTGS), the ZimSwitch system, the Zipit payment system and mobile money platforms such as Ecocash, One Money, and Telecash among others in Zimbabwe. The collapse of such interlinked and interdependent systems will severely undermine confidence in the banking sector and lead to an infrastructure meltdown and loss of crucial connectivity among banks hence these vulnerabilities have to be identified and mitigated. In fact the current Covid-19 crisis has exposed weak spots in the Zimbabwean financial market with potential effects that may echo in other sectors of the economy. Managing these resources as a network of banks is crucial during disasters. The need for solid industry level BCM that guarantees 
quick disaster recovery is therefore not questionable.

Effective BCM for banks also requires constant supplies of electricity. Sekhar (2014) argues that "there is no walk of life in which electricity is not used these days". Non-availability of electricity totally disrupts bank operations. A BCM model devoid of power supply considerations and fall back options is not ideal. Erratic power supplies in Zimbabwe have forced most banks to install power backup systems at their buildings in the form of diesel powered generators or solar systems. A study by the U.S. Government (2007) found that backup power plays an important recovery role in all disasters. In addition permanent backup systems can sustain facilities through extended utilities outages. Banks must therefore incorporate an emergency power plan in their BCM model. The power backup plan should have the capacity to carry the load for all critical operations with both onsite and offsite options.

Awareness and training is another vital consideration for effective BCM in Zimbabwean banks. Clark (2015) suggests that practicing BCM as part of the training process should not be neglected as that entrenches BCM consciousness. As suggested by Khanna (2008), awareness and training give both internal and external stakeholders such as employees and customers and shareholders confidence in the organization's ability for orderly recovery in the event of a disaster. Awareness and training guarantees full preparedness for the bank and will minimize the shock of surprise announcements from regulators dealing with the effects of a disaster. All employees of the organization from the general employee to the executive must be aware of their roles and responsibilities in the response to the recovery effort to prevent an obvious waste of resources. Training enables banks to introduce new strategies to the BCM model in place and to test the BCM knowledge level among stakeholders. Graham and Kay (2006) found out that training communicates a well-defined and approved BCM vision and thus embeds a BCM culture in the organization. Banks need to work out the various and feasible combinations of delivering training to all employees. Clearly, effective BCM requires banks to deploy BCM training that will prepare banks to gracefully recover from disasters.

Learning from Niemimaa et al. (2019), effective BCM should also take into consideration the business model adopted by the bank and not just the processes and resources through which it is accomplished. Kruskal et al. (2021) examined radiology businesses in the USA and found that a series of strategic and operational changes depending on the business model and other factors were implemented among radiology businesses in the USA. As already noted, Ayadi (2019) suggests that there is need to understand the risk behavior of the bank business model in the design of the BCM model. This is argued to expand the scope of $\mathrm{BCM}$ from value preservation to value creation and make BCM more holistic and strategic. Burtles (2016) also found that BCM is about defending and preserving the brand in a time of crisis using an emergency response. Additionally, they note that pandemics of the nature and magnitude of Covid-19 have 
potential to render many established business models and brands obsolete. It is also noted that when operational disruptions are prolonged, they create immediate and substantial losses and prevent the achievement of strategic goals of any organization. Based on the above findings, our study posits that banks are now under severe pressure to renew their business models in order to survive the negative impact of the Covid-19 pandemic and avoid gradually fading into non-competitiveness. Additionally, our study advances the argument that rethinking business models adopted by individual banks is crucial for BCM managers.

Other supportive factors and BCM ingredients observed by Kruskal et al. (2021) from their study of radiology business in the USA include timely reduction of business expenses, monitoring and management of cash reserves available, effective leadership and communication strategies, maintaining a healthy and adequately staffed team, supporting remote work environments and flexible staffing models, embracing digital media for communications, careful attention to current and new stakeholders and their service needs and an early focus on redesigning the structure and functions of the organization. A study by Barman et al. (2021) on the impact of Covid-19 on the food supply chain also concluded that concentrating on employees' health and safety and improving their working conditions are crucial requirements for business survival under Covid-19 conditions. Clearly, these are some of the important considerations for effective BCM under Covid-19 conditions.

\subsection{The Impact of Covid-19 on Business Operations}

Literature on the impact of Covid-19 on business operations is rapidly growing. Carracedo, Puertas, Marti (2020) found that in a little over three months, the whole world struggled to curb Covid-19 and its economic consequences that exposed the fragility of all modern economies. Unprecedented changes and transformation of businesses in the context of Covid-19 are inevitable though research on the impact of Covid-19 on business Operations is still developing. Research done so far has shown that Covid-19 substantially affects operations for both essential and non-essential business in various ways as most businesses did not see Covid-19 coming due to lack of capacity to predict changes and threats within the business environment. While the magnitude of impact varies across the globe, the deadliest pandemic the world has so far seen has not spared most aspects of business operations. Asare et al. (2020) found that businesses have lost stock market value, some have downsized or closed temporarily while some have collapsed. Kruskal et al. (2021) also found that the surge in the Covid-19 pandemic seen in 2020 has caused serious operational, financial and personal impacts on radiology businesses in the USA. Asare et al. (2020) further confirm that financial, supply chain and operational disruptions and cash flow constraints have emerged as topical challenges imposed by Covid-19. This resonates with the argument that businesses suffered a severe drop in orders, reduc- 
tions in supplies and started enduring changes in spending habits by their customers at the onset of the pandemic (Carracedo, Puertas, \& Marti, 2020). Furthermore, loss of human capital skills through death and retrenchment of key personnel is another challenge that cuts across most businesses around the globe. Asare et al. (2020) refer to job losses of around 26 million in the USA and 1 million in Canada, as figures which are indicative of the global extent of job losses. Given these challenges faced by businesses, these scholars suggest that the use of agility dimensions, artificial intelligence, and data analytics capabilities such as consciousness, accessibility, decisiveness, speed, and flexibility is recommended. It is also recommended that deploying administrative strategies that include perceiving threats as opportunities, building stakeholder loyalty and trust and human capital investment and retention help businesses stay competitive and resilient under Covid-19 conditions.

\subsection{The Efficacy of Online Platforms and Channel Integration in Disaster Times}

Bank-customer relationships can exist in cyberspace (Kassim \& Abdulla, 2008). Implied is that banks can deliver products and services to customers they have never seen using the internet. OKe and Dada (2017) write that banks should awake to new technology which allows them to provide optimal service delivery to their clients at reasonable profit and cost levels. Similarly, Asare et al. (2020) explain that businesses should not shy away from trying new technologies during this Covid-19 emergency period. Referring to Radiology businesses in the USA, Kruskal et al. (2021) note that Covid-19 presented the opportunity to move from clinical service delivery to tele-health. Thus, moving to new ICT enabled channels is not unique to banks alone. New technologies benefit banks in many ways. The rapid development and evolution of products are made possible by information communication technologies. Leveraging internet capabilities can help banks deliver higher levels of value to customers that include individualization and greater interaction. The internet also provides scope for e-marketing and e-procurement which generate considerable cost savings for banks. The ICT space thus offers many opportunities for banks to exceed customer expectations.

Omarini (2013) found that banks can also leverage multi-channel or multi-accesses to bank services by clients because bank products can be easily virtualized. Channel integration connotes that banks need to continue searching for the optimum mix of channels to efficiently integrate various contact points with their customers as highlighted by Osterlund et al. (2005). Pervious researches by Craig (2000); Friedman and Furey (1999) also emphasize the importance of combing financial services delivery channels. Similarly, Sultan and Rohm (2004) also found that interweaving all channels into an integrated and streamlined organizational structure is a prerequisite for effective channel integration. Referring to Sultan and Rohm (2004); Steinfield (2002) and Berman and Thelen 
(2004), Osterlund et al. (2005) note that channel integration should permit customers to move freely between channels. This clearly requires articulate planning, coordination and control that effectively links the multiple channels.

Covid-19 has imposed pressure on banks to manage and satisfy customer needs using different channels and to grow channels with low uptake by customers as ways to increase revenue and reduce pressure from increased costs induced by the Covid-19 pandemic. Research has shown that market compelling services can be offered through traditional banking under brick and mortar branches, Automated Teller Machines (ATMs), telephone banking through branchless intermediaries, PC banking, E-banking or internet banking; mobile banking (Chirima \& Chikochi, 2016; Batiz-Lazo \& Wood, 2002; Batiz-Lazo \& Wardley, 2007; Flier et al., 2003); video kiosks (Osterlund et al., 2005) and in-store banking (Mutengezanwa et al., 2011). The banking sector is however known to be sensitive and open to technology developments and this provides an opportunity for banks to capitalize on innovative technologies for them to neutralize the impact of disruptive forces. Creating online digital channels is important to ensure seamless cross-channel customer experiences. Banks now have a choice to collaborate with third party payment service providers (TPPSP) to go beyond financial services and offer value added services to their clients. Omarini (2013) found that web-based technologies are now expansively used by banks and stresses that banks can ride on the internet experience to develop multi-platform banking business that is technology driven. It is further affirmed that banks need to aggressively migrate their customers to internet based banking channels for them to realize cost savings and improve revenue per customer and create value for clients.

Online platforms and channel integration offers banks benefits that include: reduced transaction processing costs; improved customer convenience; a powerful marketing and customer relationship management tool, better customer acquisition and retention; value added cross selling of additional financial services; enhanced problem detection and resolution (Sarel \& Marmorstein, 2003; Chirima \& Chikochi, 2016); detection of emerging product and service trends; the possibility of creating a financial portal; the possibility of creating loyal customers and offering services to third parties. Clearly, it can be gleaned from the above that online platforms and channel integration are beneficial to banks.

Zhang, Li and Xu (2020) analyze the buy-online-and-pick-up-in-store (BOPS) as a strategy for reducing carbon emissions and highlight that this online model entails that clients search for everything they want online and pay in store. Wang, Nan, Chen and Li (2020) also studied the BOPS model in the retail sector and found that the model is gaining popularity among retailers as it increases store sales. Retailers have the option to offer service through online, offline and BOPS channels and their attendant pricing strategies. Additionally this model provides customers with a more convenient shopping experience and has proved useful in entrenching customer loyalty. When using this model, clients enjoy the 
ultimate benefit of being able to buy online and instant pick up which saves on travel costs and psychological costs of waiting. Empirical evidence shows that this dual-channel approach led to increased sales for major retailers in the USA and China suggesting that the BOPS is an effective sales strategy that promotes sales and profitability. As suggested by Luarn and Lin (2003), banks can offer some of their services via pure e-commerce though pure e-commerce is not possible on some products which require delivery or collection. Furthermore, Wang, Nan, Chen and Li (2020) note that customers now demand seamless shopping experiences across online and physical channels and learning from this, banks can put the BOPS model to a test. The BOPS model for example offers clients pick up convenience, real time inventory information, express collection lanes, reduced packaging time and dedicated parking. As a result, an era of omni-channel retailing is coming and this implies the "multi-channel and cross channel integration of available channels." Bank customers in Zimbabwe have endured tiring waiting times for cash and other services hence this model presents an opportunity to be tested in Zimbabwe where banks can include an online booking system that allows customers to instantly get served and pick up their cash. Such a model would allow banks to meet e-customer demands.

Osterlund et al. (2005) found that a channel integration strategy mainly focuses "on issues related to costs, channel choices and strategic choices." In addition, coordination and integration of the various tasks previously performed by different channels, is important. Banks in Zimbabwe however have to also consider factors that barricade a multi-channel approach such as culture, data costs, internet penetration, the functional value of online platforms, information security concerns, laws and regulations and the profiles of their customers. Omarini (2013) suggests that banks need to convince their clients that online platforms are secure but in a manner which does not cannibalize traditional banking channels. Banks therefore need to persuade existing and new clients to sign up on online banking channels while focusing on creating different banking experiences and rethinking the entire value chain in retail banking. At this stage, it can be suggested that banks should tune their available channels to be complementary in response to customers' needs during crisis times while the quality of online services should exceed customer expectations

\subsection{Leveraging Customer Loyalty in Crisis Times}

The Covid-19 pandemic has altered interactions between businesses and their stakeholders. Asare et al. (2020) write that many businesses are concerned about their relationship with customers and other stakeholders during the Covid-19 pandemic period. Customer loyalty is crucial for business survival according to Reichheld and Schefter (2000). Kassim and Abdulla (2008) found that several definitions of customer loyalty "argue that customer loyalty involves both attitudinal and behavioral components" while strong attitudinal loyalty must precede true loyalty. Given that, loyalty is therefore a strongly held commitment 
to continue doing business consistently with an organization in the future. Customer loyalty arises from meeting or exceeding customer expectations in a manner that builds customer confidence over a period of time. Customer confidence is therefore a critical foundation for customer loyalty to be realized.

Hoq and Amin (2010) found that customer satisfaction reduces customers' intention to switch banks. Learning from Sivadass and Baker-Prewitt (2000); Chakravarty, Feinberg and Rhee (2004); and Ibok (2009), our study found that customer satisfaction and ultimately customer loyalty result from the interaction of factors that include fast and efficient service, confidentiality, speed of transaction, staff quality, corporate architecture, accuracy and timeliness of billing system, competitive pricing and service quality. Thus, Liu, Li, Tao and Wang, (2008) argue that customer satisfaction needs to be measured using criteria that focus on satisfaction, content, relived, novelty and surprise. Implied is that banks should strive to ascertain the perception developed by customers about the products and services offered, understand the features of their products and services and how they benefit customers, work towards alleviating any negative experiences suffered by customers, ensure that products and services bring freshness and excitement in customers and finally ensure that consumed products and services bring amazement and surprise to customers. The concepts of trust, perceived value and customer satisfaction were also analyzed by Luarn and Lin (2003) who write that these factors directly lead to loyalty but have an indirect path to loyalty through commitment hence commitment exerts a stronger influence on customer loyalty. Implied is that the formation of trust, customer service and perceived value should be properly managed to realize customer loyalty through a satisfying brand.

A study by Samraz and Bakhtiar (2012) cited in OKe and Dada (2017) concluded that service quality, customer satisfaction and loyalty programs are the important factors that can increase the loyalty of a customer, so banks must focus on providing loyalty programs to their loyal and valued customers. Findings by Luarn and Lin (2003) also show that "trust, customer satisfaction, perceived value, and commitment are separate constructs that combine to determine the loyalty, with commitment exerting a stronger influence than trust, customer satisfaction, and perceived value." Similarly, a study by Kassim and Abdulla (2008) found that service quality positively affects customer satisfaction and trust while both customer satisfaction and trust positively influence customer loyalty. Another study by Ibok and Akpan (2013) also found out that bank customers want instant service irrespective of the situation and that this has an effect on customer satisfaction and loyalty. Banks therefore should strive to offer fast and efficient service even in times of disasters. Lessons from studies by Oke (2012) and Nwaeze, Anetor, and Egwu (2016) cited in Oke and Dada (2017) are that marketing positively influences bank performance and that banks should enhance rewards on different accounts to increase customer patronage. By extension, the acquired patronage will help banks sustain their operations in difficult 
operating environments.

Oke and Dada (2017) also found out that there is a positive relationship between pricing and customer satisfaction and recommend that banks should improve customer satisfaction to maximize performance. This observation is also noted by Luarn and Lin (2003) who write that to realize high levels of customer loyalty and commitment, managers need to improve consumer perceived value through increasing their product/service and website quality and pricing their products/services reasonably. Other studies also concluded that brand loyalty leads to advantages that include reduced marketing costs, winning more new customers, greater trade leverage, winning market share, and developing sustainable competitive advantage (Luarn \& Lin, 2003). Mutengezanwa et al. (2011) established that challenges faced by banks were loss of customer confidence, stiff competition and failure by the Central bank to perform the role of lender of last resort in Zimbabwe, factors which negatively affect customer loyalty and confidence in banks. A synthesis of the above evidence suggests that if banks in Zimbabwe focus on customer satisfaction and service quality, value addition, building trust and commitment among customers they may realize improved resilience to Covid-19 induced challenges. Understanding the interrelationship between bank performance, customer satisfaction, customer loyalty and business continuity is however important. A thorough appreciation of customer loyalty trends and managerial decision implications in the context of the Covid-19 environment is also a crucial construct.

\subsection{Pricing Strategies for Commercial Banks}

Pricing strategies for bank products have never been as important as in the current global Covid-19 crisis period. Banks in Zimbabwe play a prominent role in the economy. It is against this backdrop that this section examines the pricing of bank products in a territory characterized by stiff competition and the current Covid-19 enforced operational challenges. Learning from Kotler and Armstrong (2008), price is the amount of money charged for a product or service. Certina and Mihail (2015) state that all organizations must set a price for all products and services they offer. This directs attention to the importance of carefully selecting a novel pricing model for products and services offered by the business. Oke and Dada (2017), assert that a pricing strategy is a signal in the market which influences the supply and demand of financial products. Wruuck (2013) also writes that the price of bank products is important for the reason that it influences customer satisfaction, bank profitability and the behavior of clients to switch banks among other important considerations. The above narratives clearly show that appropriate pricing is a fundamental consideration for banks at any stage of their banking business. As pointed out by Oke and Dada (2017), the need to "evaluate and determine the usefulness, effectiveness and appropriateness of these pricing regimes and promotional programs has become very urgent in order to reduce loss of public confidence, waste of time, energy and other re- 
sources".

The pricing of bank products in Zimbabwe was found to be mainly influenced by the profit motive, competition and the need to abide by regulations. In addition, strategies used to set the prices are mainly based on cost, competition and market trends (Mutengezanwa et al., 2011). This resonates with findings by Kucher (2010) who notes that pricing of bank products is mainly focused on costs and competitor prices. An improvement in pricing strategies has a positive impact on the survival of banks in any economy. Price affects the total cost and influences the choices made by bank clients. Certina and Mihail (2015) agree that setting the correct prices is fundamental for an effective marketing strategy for bank financial services. In that regard, Chen, Nan and Li (2018) examine the adoption of a wholesale pricing model or the agency pricing model in online retail platforms and note the pricing implications of adopting these models. Though the wholesale model dominates because it is profitable for retailers at low costs (Wirl, 2018), these scholars explain that consumer surplus and social welfare increase when the agency pricing model is adopted because the profits of suppliers are lower under the agency model (Johnson, 2018) but depending on the bargaining power of firms, prices will be higher or lower (De Los Santos, O'Brien, \& Wildenbeest, 2020). In addition, when customer loyalty is strong, the agency pricing model is recommended. It is worth noting upfront that adopting these pricing models for banks in Zimbabwe may require substantial alterations to business models for some banks while those with existing agency banking networks may find the approaches relatively easy to apply. However, pricing is not the only competitive weapon as bank customers consider other value adding services accompanying the whole service package offered by banks.

Pricing of bank products is complex according to Mutengezanwa et al. (2011) and is usually caught between many internal and external factors as observed by Cetina and Mihail (2015) who note that a very large range of factors influences the price. Banks must price their services above the production and commercialization costs incurred in order to survive on the market but not too high as that may contribute to loss of customers to competitors. Cetina and Mihail (2015) further emphasize that the pricing policy must be flexible and pay special attention to customer segments. Factors which influence optimal pricing include company objectives on sales and market share growth, competition, profitability and return on capital among others. Pricing is also affected by laws and regulations and policy directives. Laws and regulations enable governments to intervene and facilitate fair trade and achieve economic goals (Wuebker et al., 2008). Pricing is also driven by competition. Research has shown that most banks face competition by undercutting prices or keeping then stable. Strong competition results in significantly low prices for banking products. Mutengezanwa et al. (2011) note that competitive pressures force banks to charge low prices and to pay interest on a large proportion of deposits.

Pricing of bank products is also affected by technological changes. Technology 
adoption has brought dramatic change to banking business and is seen as a source of efficiencies. As already highlighted by Mzumara (2006), banks that lead in technology adoption are able to attract more customers, meet their expectations and offer innovative products at low cost. In fact, Cetina and Mihail (2015) agree that offering irreproachable service which surprises customers and exceeds their expectations has a positive effect on the price of the service offered by banks. Pricing of bank products is also affected by other factors such as risk, the marketing mix, shareholders and consumers of the products. This aligns with Cetina and Mihail's (2015) list of the factors that affect the formation of prices which includes the structure of the costs, the shareholders, the consumers, risk, competition, legal restrictions and objectives of the pricing policy.

Research on pricing strategies adopted by commercial banks in Zimbabwe has shown that the dominant strategy is market oriented followed by the competition based and lastly cost based pricing strategy (Mutengezanwa et al., 2011). However, banks in Zimbabwe still face challenges in pricing their products due to lack of customer confidence, stiff competition and other economic difficulties. Pricing is very important because if a product or service is given a wrong price, it may fail as sales and price of the product are related. The appropriateness of the price is thus important for banks to realize improved performance and survive in turbulent times.

Cetina and Mihail (2015) identify six (6) strategies that are used by banks when pricing their products and services. The first strategy is the cost plus profit strategy. This approach requires banks to calculate how much it costs to design and launch a product and then add a margin to get the price that customers pay. The second strategy is the "taking the cream" strategy. This approach is applied on new products that are of high quality and are introduced into the market to maximize profits and attract high value clients to recoup research and development costs. The price can be reduced at a later stage to increase demand for the product. The third strategy is the competition based strategy. This requires banks to check the prices charged by competitors on similar products and services and match them while ensuring that costs are fully covered since in some cases production costs of the product are not covered. The fourth strategy is the market based strategy. This approach requires banks to match the prices of the same products already existing on the market. The fifth strategy is the value based strategy. This strategy is based on the perception of value held by clients and is more oriented towards marketing. It answers the question, "how much will a client pay for this?" PWC (2019) notes that this approach works when banks understand the customers' willingness to pay a premium on products and services offered by the bank. The sixth strategy is the market penetration strategy. This approach requires banks to charge a low price with the goal of penetrating and winning a lion's share of the market. Banks may also need to consider adopting an individually negotiated pricing approach with corporates as a way to retain their business. 
A study on banks in India by PWC also observed that the commonly used pricing strategies are cost-plus and market-based approaches in a largely underpenetrated market with little scope for innovation. These traditional costing approaches however miss important aspects of the cost structure of banking products and services such as cost of technology, product development, roll out and infrastructure and cost of processes. Dynamic pricing, which entails real-time price adjustments based on demand and has worked in other sectors of the economy remains an opportunity for banks. Similarly, loyalty pricing and behavioral pricing, which are fairly new concepts, provide banks with an opportunity for price differentiation based on product types and customers' preferences or buying history respectively. These pricing approaches have also proved useful in helping banks increase their market share (PWC, 2019). Clearly, banks require an elaborate and innovative pricing strategy and intensification of marketing that counters the impact of Covid-19 on the performance and survival of banks.

\subsection{Business Recovery}

Post-disaster business recovery is increasingly becoming an important subject which aims at future proofing businesses from the catastrophic impact of similar occurrences as noted by Morrish and Jones (2020). Implied is that business recovery mainly focuses on enterprise survival. Some of the important business recovery considerations are outlined below. Dahlhamer and Tierney (1998) argue that business recovery can be predicted by assessing the physical impact of the disaster on a business' operations and the financial condition of the business in the long term. Business recovery incorporates the development of new resilience measures that will allow businesses to navigate disaster periods. Business survival and recovery also entail adopting specific activities and processes. Business recovery also takes into consideration possible relocation of the business activities were operations are halted by destruction and inaccessibility of premises. Decentralizing operations is congruent with Covid-19 guidelines and most businesses have decentralized from their head offices to selected BCM locations and home working settings.

Post disaster business recovery also includes interventions by governments at both the national and local authority levels though a study by Orhan (2016) found that government involvement may slow business recovery. Governments must move with speed to restore trading so that business revenue streams are quickly restored. Governments also need to support business continuation insurance, wage and relocation support in disaster times. Business recovery also requires support in the form of access to resources particularly capital. Access to grants as suggested by De Mel, McKenzie, and Woodruff (2011) may help businesses recover to pre disaster profit levels but should be allowed without creating worse off debt scenarios that may lead to bankruptcy. Resource organizing and leveraging is crucial for banks in Zimbabwe.

Effective business recovery also requires a thorough understanding of the 
pre-disaster, the disaster and the post disaster environments. This understanding is crucial for businesses before they embark on the road to recovery. There is no doubt that a new community will exist post Covid-19 pandemic and banks in Zimbabwe must take time to understand the composition of the new community. Post disaster business recovery also requires businesses to focus on attracting and retaining critical skills. Morish and Jones (2020) refer to attracting employees and skills retention as one of the major challenges faced by companies affected by the earthquake in New Zealand in 2010. LeSage et al. (2011) also suggest that business have to invest in repairs necessary for restoring business operations. An opportunity seeking behavior is also another crucial business recovery ingredient in the context of the "new normal". Recognizing opportunities should be deliberate and action must be taken to exploit possible and available opportunities to achieve desired ends. An entrepreneurial mindset is thus required to overcome the hurdles presented by disasters.

Flexible planning and swift decision making are also crucial for business recovery as suggested by Morrish and Jones (2020). In fact, post disaster environments compel business to capitalize on every opportunity that presents itself. Decisive action on key aspects such as capital injection and changing the business model to effectively adapt to the "new normal" is crucial. Changing and adapting the business model to new circumstances is however suggested to require new partners as was the case with some hospitality businesses in New Zealand. With the new model came the need for collaboration and formation of clusters which meant sharing of knowledge, resources, risks and profits. According to Fang and Zhou (2012), the adopted business model has to be compatible with business development through the internet. This is worth noting for banking businesses in Zimbabwe.

\section{Presentation and Discussion of Findings}

\subsection{BCM Approaches Common among Banks in Zimbabwe}

The main thrust of BCM among Zimbabwean banks is to provide business-as-usual processes even after a disaster through organized disaster recovery. Hiles (2010) notes that BCM planning targets risks associated with natural disasters, fires and explosions, terrorism, and floods among others. Narratives from the respondents reveal that BCM among Zimbabwean banks mainly concentrates on breakdowns in functional systems; virus attacks on core systems and loss of vital data; connectivity disruptions; loss of expertise; disasters such as fires in buildings; robberies; setting up of back-up sites in secondary or off-site buildings where staff can quickly travel to, to resume operations; raising awareness on escape routes from buildings and identifying central gathering points; identifying lead personnel in the event of a disaster who would direct and guide as well as communicate with all members of their teams and report to management in the event of a disaster. Another narrative is that existing BCM models were designed to handle disruptions due to wars, changes in government and any disruptions related to politics, 
earthquakes, system down-times and floods. Data analysis also shows that existing models envisaged scenarios, apart from the Covid-19 pandemic, that would allow employees to resume critical operations from designated off-site locations with fully functional systems, telephones and easy accessibility in the event of a disaster. Another narrative provided by one BCM manager is that his bank's model is basically designed to manage offline operations of the bank before normal resumption of business and the BCM model covers all risk threats on banking operations such as loss of human capital, physical assets, confidential records, bribery and corruption, disruptions on treasury operations and liquidity management among others.

However, mixed views regarding the suitability of these models to handle the impact of the Covid-19 pandemic emerged. Views from respondents suggest that the Covid-19 pandemic exposed obvious gaps in most BCM models adopted by banks. One respondent noted that BCM is not taken serious in the Zimbabwean context due less prevalence of disasters and once annually they just test systems but not to a $100 \%$ level of confidence and they have never worked from the BCM site. Others noted that the BCM site covers some aspects of the bank but it is not certain if the site allows employees to move in and instantly start operating. Another narrative is that lack of preparedness to equip staff to work remotely was an obvious gap as most staff members used desktop computers. In addition, it was also noted that the existing BCM model did not cater for connectivity at employees' homes and the new spacing requirements. This was reinforced by one BCM manager who noted that "Covid-19 is the first of its kind and it exposed some gaps on the existing BCM model as not all staff members were equipped to work remotely." While others described existing models as fit for purpose and ideal to enable some banks to re-launch operations without serious disruptions, some noted that existing models partly met the business recovery needs of the bank. Another dominant thread emerging from submissions made by respondents is that to a larger extent most BCM models mitigated the impact of the Covid-19 pandemic but WHO and national health recommendations and directives meant new costs for banks in terms of expanding working space and realignment of resources to suit advanced operational demands. A generally shared observation is that it was far-fetched for the existing models to anticipate a disaster of the nature of the Covid-19 pandemic and banks had to accept alterations to existing models to mitigate the impact of the Covid-19 pandemic.

\subsection{Implications of the Covid-19 Pandemic on Banks in Zimbabwe}

Wide-area disasters such as the Covid-19 pandemic have immediate operational implications and an excruciating aftermath. Banks in Zimbabwe never imagined a crisis of this nature as already noted above but had fair warning and time to prepare for threatening pandemic. One respondent specifically noted that risk 
modelling or stress testing in Zimbabwe, in most cases, did not include pandemics before the Covid-19 pandemic even though the concept of BCM caters for the unforeseen which may include any event with adverse effects on the operations of banks. What has become noticeable is that banks are experiencing challenges such as delayed opening hours due to acute transport shortages, loss of critical staff members due to transport restrictions, failure to open doors to the public for over the counter services and loss of access to critical ICT resources among others. In addition, banks faced an unprecedented demand for online banking services. These and other challenges are discussed in detail below.

The Covid-19 pandemic presented transport challenges for bank employees in Zimbabwe. There is a shared consensus among respondents that due to the Covid-19 pandemic, banks find it problematic to transport all their employees to their places of work for various reasons. Firstly, providing fuel to all affected employees would elevate operating costs to astronomic levels. Secondly, fuel availability in Zimbabwe is in itself a major predicament not only for banks but for the entire economy. Thirdly, even if employees use their own personal vehicles, lockdown restrictions, particularly on travel, discourage easy access to most central business districts across the country thereby frustrating any effort to get to work on time. Transport for bank employees clearly became a challenge for most banks and it is reasonable to point out that in such cases access to active bank premises and back-up sites becomes problematic hence banks in Zimbabwe must rethink their current BCM models.

The Covid-19 pandemic imposed staff spacing restrictions on Banks in Zimbabwe. Narratives from respondents reveal that banks found themselves exposed to an immediate shortage of space due to spacing requirements incorporated in the Covid-19 restrictions and regulations. One respondent noted that banks realized inadequacies related to the brick and mortar model common among most banks in Zimbabwe as they could not accommodate all employees due to spacing requirements. Another respondent noted that most banks had an open office system in place which meant that a whole department for example shared one common office. In such circumstances, it became obvious that introducing the stipulated spacing requirements would trigger space shortages. One BCM manager clearly noted that WHO and national health recommendations meant new costs for banks in terms of expanding working space. Past research also acknowledges the need to rethink business models in times of crisis. For instance, Morrish and Jones (2020) found that changing and adapting the business model to the new normal is crucial for businesses to survive the after effects of a disaster. A purification of these arguments shows that office space for most banks was largely affected by the Covid-19 pandemic which has now put to test the traditional brick and mortar model common among banks in Zimbabwe.

Data analysis also shows that the Covid-19 pandemic left banks faced with an upsurge in demand for mobile ICT tools such as laptops and IPads as most 
banks relied on desktop computers for most of their employees. A generally shared view is that banks were not prepared and ready to enable their employees to work remotely. Referring to Breznitz and Zysman (2013), most bank work flows involve human mediated processes and as such, ICT tools make employees more productive. in fact, research by scholars such as Kassim and Abdulla (2008), Ojo \& Dada (2017), Asare et al. (2020), Kruskal et al. (2021), Chirima and Chikochi (2016), Omarinni (2013), Zhang, Li and Xu (2020) and Wang, Nan, Chen and Li (2020) confirm the utility of ICTs and suggest that online channels enhance banking operations in a time of crisis. In Zimbabwe, most of the banks have their workflows done online through interlinked computers with access to shared drives. Covid-19 imposed disruptions meant bank employees had to resume operations offsite but existing BCM facilities where not adequate to accommodate all affected employees due to spacing requirements and difficulties in getting employees to the sites. BCM and operations executives were faced with an operational complicatedness as service and operational disruptions were imminent. The Covid-19 pandemic effectively meant that the ability of banks to deploy core banking systems to employees' homes came under test. This clearly created an operational headache for banks in Zimbabwe as most banks temporarily suspended some operations until solutions were found.

Due to the Covid-19 pandemic, banks were also forced to suspend all over the counter services to the banking population. The high levels of restrictions such as the stay home directive meant banking halls could not open as no staff members and customers could travel to the banks. One BCM manager noted that customer service disruptions owing to "surprise" pronouncements given lack of full preparedness by banks and reduced exposure to client business needs as banks now rely on stories presented by clients instead of physical inspections adversely affected normal banking procedures. Narratives from respondents also show that closed branches meant an upsurge in demand for mobile and internet based transactions. This meant that banks with well-developed online banking platforms faced minor capacity challenges as their systems largely coped with the demand while banks that had mobile banking platforms still under development endured severe system disruptions. Bank preparedness on this aspect becomes a fundamental consideration. Learning from Muraleedharan (2014), "banking anytime and anywhere" or virtual banking was long envisaged to replace the traditional brick and mortar model. Referring to Gup (2003), dramatic changes in the banking sector due to technology provide customers with more options than those offered by the brick and mortar model of banking. As affirmed by Breznitz and Zysman (2013), bank-at-home systems now provide customers the flexibility to transact from the comfort of their homes or offices without challenges. Furthermore, Zhang, Li and Xu (2020) and Wang, Nan, Chen and Li (2020) who explored the value of online models, recommend the adoption of online models due to their ability to meet customers' e-demands. In that regard, Asare et al. (2020) exhorts banks not to shy away from technologies that improve service de- 
livery while Kruskal et al. (2021) note that Covid-19 presented an opportunity to move to digital service delivery. On line service delivery offers many benefits to banks. At a glance, it is not far-fetched to note that banks that lag behind technological advancement in their BCM models remain exposed to interruptions that may delay resumption of operations.

Other narratives also suggest that banks have suffered reduced income generation opportunities while their operating costs remain fixed and increasing in some cases. This resonates with observations by Niemimaa et al. (2019) who note that environmental contingencies present threats with potential to disrupt or diminish companies' revenue streams. A notable thread in the submissions made by respondents is that foreign currency cash circulation has been severely affected by the pandemic and this has triggered high cash importation costs for banks which now rely on chartered flights as most airlines are not operating. In addition, Covid-19 pandemic has also resulted in business and vetting models losing relevance due changing circumstances. The pandemic has also resulted in the redundancy of risk management processes and increased credit and liquidity risk. While it may be too early to confirm some of the effects of the Covid-19 pandemic on the operations and performance of banks, it is not far-fetched to anticipate severe reductions in revenue and increased operating costs for banks during the covid-19 pandemic period. Taking this into consideration, adequate pricing models as suggested by Certina and Mihail (2015), Oke and Dada (2017), Wruuck (2013), Kucher (2010), Certina and Mihail (2015), Chen, Nan, \& Li (2018), De Los Santos, O’Brien, \& Wildenbeest (2020) and PWC (2019) are crucial for covering costs and supporting business recovery.

\subsection{BCM Strategies Adopted by Banks during the Covid-19 Pandemic and the Future of BCM Approaches for Banks in Zimbabwe}

The Covid-19 pandemic has imposed changes to existing BCM models in most banks. Being the first disaster of its kind for most banks in Zimbabwe, it caught banks by surprise. Learning from Clark (2015), the Covid-19 pandemic enabled banks to "see leaking holes in their BCM roofs." Data analysis reveals some notable alterations to existing BCM models that banks cannot avoid if they are to cope with the impact of the Covid-19 pandemic. Generally, BCM changes made include enabling remote access to the banks' core banking systems; working from home; providing data bundles; providing backup power; providing internet connectivity and airtime; buying or renting laptops; providing masks; sanitizers and introducing health checks and providing transport to and from home for employees working from the office. Another notable view is that amendments to existing BCM models are still in progress and await senior management validation upon completion of the recommendations on capacitation of employees to work remotely. Given the above views, it is reasonable to note that BCM in most banks in Zimbabwe is still reacting to the impact of the Covid-19 pandemic and 
evolving to address attendant challenges. This resonates with Brooks et al.'s (2007) argument that BCM models need to evolve to adequately meet emerging challenges. Clearly, the future of BCM in banks should incorporate planning in advance for health disasters or pandemics of the nature and magnitude of the Covid-19 pandemic.

\section{Conclusion and Recommendation for Future Research}

This study is a response to the need to examine BCM approaches adopted by banks at the onset of and during the Covid-19 pandemic period. BCM in the banking sector is fundamentally more important now than before the Covid-19 pandemic. Banks in Zimbabwe had never imagined a crisis of the nature and magnitude of the Covid-19 pandemic thus clearly exposing gaps in existing BCM approaches. The inadequacies of the current BCM capabilities will continue to drive improvements that are in sync with the impact of the Covid-19 pandemic and that include the ability to anticipate surprises. The study supports the improvement of BCM approaches among banks in Zimbabwe by proposing that banks should focus more on building BCM approaches that guarantee resilience and quick recovery from unexpected disasters of the magnitude of the Covid-19 pandemic. The Covid-19 pandemic has indeed injected a powerful consciousness in most banks on the importance of preparing in advance for likely and unforeseen impacts of pandemics. BCM practice in the banking sector, which until now has been a luxury will remain a necessity after the Covid-19 pandemic. Banks need to develop strategies for effective BCM that guarantees harmonized business recovery in a time of crisis and this can be achieved using models such as the split operations model. Other strategies include intense analysis of information about the disaster; compliance with laws; regulations and directives; training and awareness and a clear understanding of the nature of the bank's business model. Technological and human resources that will enable banks to operate under adverse conditions are equally important considerations. Banks should also adopt a multi-channel approach which prefers electronic delivery over paper based delivery of services to clients. In addition, appropriate pricing strategies would equally enhance bank performance during the period of the Covid-19 emergence. Complementing this strategy with investing in customer satisfaction, trust and perceived value to enhance customer loyalty is crucial. It is clear from our study that banks are dancing to the Covid-19 drum beat and BCM for banks in Zimbabwe will largely be influenced by the heartbeat of the Covid-19 pandemic into the foreseeable future while beyond the pandemic, banks must race to re-establish their positions in the market.

However, like any other study, this study has some limitations which can be addressed by future research given that findings are based on data collected from a small number of banks in Zimbabwe only and that non-banking institutions did not form part of the study. Secondly, the study was done over a short period of time. Caution must therefore be taken when comparing BCM strategies stated 
in the findings of this study with those adopted by banks in other countries. The study recommends that further research be done to determine if non-banking institutions are facing the same challenges as banks due to Covid-19 and if the same strategies used by banks are applicable to non-banking institutions. The study mainly focused on banks in Zimbabwe, further comparative research needs to be done to understand BCM approaches used by banks in other developing countries. The study was done at the onset of the Covid-19 pandemic hence there is also need for further research over a long period of time to establish the full impact of Covid-19 on BCM strategies adopted by banks in Zimbabwe. This study does not rely on advanced statistical methods hence quantitative studies may also be done to determine the impact of the Covid-19 pandemic on BCM among banks in Zimbabwe.

\section{Acknowledgements}

The authors of this study appreciate the work done by the editor and reviewers for the comments and suggestions that were very helpful and insightful.

\section{Conflicts of Interest}

The authors declare no conflicts of interest regarding the publication of this paper.

\section{References}

Abu Bakar, Z., Yaacob, N. S. A., \& Udin, Z. M. (2015). Business Continuity Management Factors and Organizational Performance: A Study on the Moderating Role of It Capability. Journal of Management Info, 2, 5-12. https://doi.org/10.31580/jmi.v7i1.38

Asare, A. O., Addo, P. C., Sarpong, E. O., \& Kotei, D. (2020). COVID-19: Optimizing Business Performance through Agile Business Intelligence and Data Analytics, Open Journal of Business and Management, 8, 2071-2080. https://doi.org/10.4236/ojbm.2020.85126

Ayadi, R. (2019). Banking Business Models: Definition, Analytical Framework and Financial Stability Assessment. London: Springer. https://doi.org/10.1007/978-3-030-02248-8

Banica, A., Kourtit, K., \& Nijkamp, P. (2020). Natural Disasters as a Development Opportunity: A Spatial Economic Resilience Interpretation. Review of Regional Research, 40, 223-249. https://doi.org/10.1007/s10037-020-00141-8

Barman, A., Das, R., \& De, P. K. (2021). Impact of COVID-19 in Food Supply Chain: Disruptions and Recovery Strategy. Current Research in Behavioral Sciences, 2, Article ID 100017. https://doi.org/10.1016/j.crbeha.2021.100017

Batiz-Lazo, B., \& Wardley, P. (2007). Banking on Change: Information Systems in Technologies in UK High Street Banking 1919-1969. Financial History Review, 14, 177-205. https://doi.org/10.1017/S0968565007000534

Batiz-Lazo, B., \& Wood, D. (2002). Historical Appraisal of Information Technology and Commercial Banking. Electronic Markets, 12, 192-205. https://doi.org/10.1080/101967802320245965

Berman, B., \& Thelen, S. (2004). A Guide to Developing and Managing a Well-Integrated 
Multi-Channel Retail Strategy. International Journal of Retail and Distribution Management, 32, 147-156. https://doi.org/10.1108/09590550410524939

Breznitz, D., \& Zysman, J. (2013). The Third Globalization: Can Wealthy Nations Stay Rich in the Twenty-First Century? Oxford: Oxford University Press. https://doi.org/10.1093/acprof:oso/9780199917822.001.0001

Brooks, C., Leung, C., Mirza, A., Neal, C., Qiu, Y. L., Sing, J., Wong, F. T., \& Wright, I. R. (2007). IBM System Storage Business Continuity: Part 1 Planning Guide. IBM, International Technical Support Organization.

https://books.google.co.zw/books?id=due1AgAAQBAJ\&pg=PA29\&dq=Business+Conti nuity+Mod-els\&hl=en\&sa=X\&ved=0ahUKEwiy0LKt u pAhWRonEKHSyzCQgQ6AE IJjAA\# $\mathrm{v}=$ onepage $\& \mathrm{q}=$ Business $\% 20$ Continuity $\% 20$ Models $\& \mathrm{f}=$ false

Burtles, J. (2016). Principles and Practice of Business Bontinuity: Tools and Techniques (2nd ed.). Brookfield, CT: Rothstein Publishing.

Carracedo, P., Puertas, R. Marti, L (2020). Research Lines on the Impact of the COVID-19 Pandemic on Business. A Text Mining Analysis. Journal of Business Research. (In Press) https://doi.org/10.1016/j.jbusres.2020.11.043

Cetina, I., \& Mihail, N. (2015). Price Strategies in Banking Marketing. Journal of Economic Theoretical Application, 25-32.

Cetina, L., \& Mihail, N. (2015). Price Strategies in Banking Marketing. https://www.researchgate.net/publication/4730960

Chakravarty, S., Feinberg, R., \& Rhee, E.-Y. (2004). Relationships and Individuals Bank Switching Bahaviour. Journal of Economics and Psychology, 25, 507-527. https://doi.org/10.1016/S0167-4870(03)00051-5

Chen, L., Nan, G., \& Li, M. (2018). Wholesale Pricing or Agency Pricing on Online Retail Platforms: The Effects of Customer Loyalty. International Journal of Electronic Commerce, 22, 576-608. https://doi.org/10.1080/10864415.2018.1485086

Chirima, D. T., \& Chikochi, K. (2016). The Impact of Electronic Banking on the Competitiveness of Commercial Banks in Zimbabwe (2014-2015). Case Studies Journal, 5, 13-20.

Clark, R. (2015). Validating Your Business Continuity Plan. Cambridgeshire: IT Governance Ltd.

Craig, T. (2000). Clicks without Bricks Just Doesn't Pay the Bills. Discount Store News, $39,13$.

Dahlhamer, J. M., \& Tierney, K. J. (1998). Rebounding from Disruptive Events: Business Recovery Following the Northridge Earthquake. Sociological Spectrum, 18, 121-141. https://doi.org/10.1080/02732173.1998.9982189

De Los Santos, B., O’Brien, D. P., \& Wildenbeest, M. R. (2020). Agency Pricing and Bargaining: Evidence from the e-Book Market.

http://www.host.kelly.ie.edu/mwildenb/ebooksbargaining.pdf

De Mel, S., McKenzie, D., \& Woodruff, C. (2011). Enterprise Recovery Following Natural Disasters. The Economic Journal, 122, 64-91. https://doi.org/10.1111/j.1468-0297.2011.02475.x

Elliott, D., Swarts, E., \& Herbane, B. (2010). Business Continuity Management: A Crisis Management Approach. New York: Routledge.

Estall, H. (2012). Business Continuity Management Systems: Implementation and Certification to ISO 22301. Chippenham: BCS, The Chartered Institute.

Fang, X., \& Zhou, Y. (2012). Internet-Future Business Development Focus. American 
Journal of Industrial and Business Management, 2, 85-88.

https://doi.org/10.4236/ajibm.2012.23011

Flier, B., Van den Bosch, A. J., \& Volberda, H. W. (2003). Co-Evolution in Strategic Renewal Behaviour of British, Dutch and French Financial Incumbents: Interaction of Environmental Selection, Institutional Effects and Managerial Intentionality. Journal of Management Studies, 40, 2163-2187. https://doi.org/10.1046/j.1467-6486.2003.00416.x

Friedman, L. G., \& Furey, T. R. (1999). Channel Advantage: Going to Market with Multiple Sales Channels to Reach More Customers, Sell More Products, Make More Profit. Oxford: Butterworth-Heinemann.

Graham, J., \& Kaye. D. (2006). A Risk Management Approach to Business Continuity: Aligning Business Continuity with Corporate Governance. Connecticut: Phillip Jan Rothstein, FBCI.

Gup, B. E. (2003). The Future of Banking. Westport: Quorum Books.

Heng, G. M. (2007). Managing and Sustaining Your Business Continuity Management Program. Singapore: GMH Pte Ltd.

Hiles, A. (2010). The Definitive Handbook of Business Continuity Management. West Sussex: John Wiley and Sons.

Hoq, M. Z., \& Amin, M. (2010). The Role of Customer Satisfaction to Enhance Customer Loyalty. African Journal of Business Management, 4, 2385-2392.

Ibok, N. I. (2009). Bank Characteristics as Determinants of Customer Satisfaction. Journal of Research in Management, 4, 118-124.

Ibok, N. I., \& Akpan, S. J. (2013). Investigating Customer Satisfaction Driven Values in the Retail Banking Industry. International Journal of Finance and Accounting, 2, 292-296.

Johnson, J. P. (2018). The Agency and Wholesale Models in Electronic Content Markets. https://cdn.questromworld.bu.edu/platformstrategy/files/2018/06/jpj25@cornell.edu_.p df

Kassim, N. M., \& Abdullah, N. A. (2008). Customer Loyalty in E-commerce Settings: An Empirical Study. Electronic Markets, 18, 275-290. https://doi.org/10.1080/10196780802265843

Khanna, A. (2008). Straight-Through Processing for Financial Services: The Complete Guide. Amsterdam: Academic Press.

Kotler, P., \& Armstrong, G. (2008). Principles of Marketing (12 $2^{\text {th }}$ ed.). South Africa: Pearson Prentice Hall.

Krell, E. (2006). Business Continuity Management. Canada: Society of Management Accountants of Canada. http://www.aicpa.org/

Kruskal, J. B., Rosen, M. P., Hara, A. K., Canon, C., \& Wald, C. (2021). Enabling Your Radiology Business to Thrive: Strategic Lessons Learned During the Initial and Subsequent Surges of the Covid-19 Pandemic. Academic Radiology, 28, 393-401. https://doi.org/10.1016/j.acra.2021.01.005

Kucher, S. (2010). Strategy and Marketing Consultants. Singapore. https://www.simon-kucher.com/en

LeSage, J. P., Pace, R. K., Lam, N., Campanella, R., \& Liu, X. (2011). New Orleans Business Recovery in the aftermath of Hurricane Katrina. Journal of the Royal Statistical Society: Series A (Statistics in Society), 174, 1007-1027. https://doi.org/10.1111/j.1467-985X.2011.00712.x

Liu, Y., Li, Y., Tao, L., \& Wang, Y. (2008). Relationship Stability, Trust and Relational 
Risk in Marketing Channels: Evidence from China. Industrial Marketing Management, 37, 432-446. https://doi.org/10.1016/j.indmarman.2007.04.001

Luarn, P., \& Lin, H. (2003). A Customer Loyalty Model for e-Service Context, Journal of Electronic Commerce Research, 4, 156-167.

Morrish, S. C., \& Jones, R. (2020). Post-Disaster Business Recovery: An Entrepreneurial Marketing Perspective. Journal of Business Research, 113, 83-92. https://doi.org/10.1016/j.jbusres.2019.03.041

Muraleedharan, D. (2014). Modern Banking: Theory and Practice. Delhi: PHI Learning.

Mutengezanwa, M., Mauchi, F., Njanike, K., Gombarume, F., \& Murgorgo, S. (2011). Pricing of Banking Products and Services: A Case Study of Commercial Banks in Zimbabwe. Journal of Business Administration, 1, 48-53.

Mutengezanwa, M., Mauchi, F., Njanike, K., Gombarume, F., \& Murgorgo, S. (2011). Pricing of Banking Products and Services: A Case Study of Commercial Banks in Zimbabwe. Scholarly Journal of Business Administration, 1, 48-53.

Myers, K. N. (2006). Business Continuity Strategies: Protecting against Unplanned Disasters. Danvers: John Wiley and Sons.

Mzumara, M. (2006). The Theory of Money and Banking in Modern Times. Mustang: Tate Publishing.

Niemimaa, M., Järveläinen, J., Heikkilä, M., \& Heikkilä, J. (2019). Business Continuity of Business Models: Evaluating the Resilience of Business Models for Contingencies. International Journal of Information Management, 49, 208-216. https://doi.org/10.1016/j.ijinfomgt.2019.04.010

Nwaeze, C., Anetor, E. A., \& Egwu, C. C. (2016). Impact of Marketing of Banking Services on the Profitability of Nigerian Banking Sector. The Macrotheme Review, 5, 45-59.

Ojansivu, I., \& Medlin, C. J. (2018). To Whose Drum Are We Marching? Change in Business Networks through a Contextual Logics Perspective. Industrial Marketing Management, 70, 141-155. https://doi.org/10.1016/j.indmarman.2017.08.012

Oke, M. O. (2012). Marketing Strategies and Bank Performance in Nigeria: A Post Consolidation Analysis. Global Journal of Management and Business Research, 12, 1-11.

Oke, M. O., \& Dada, O. (2017). Marketing Strategies and Bank Performance in Nigeria: A Post-Consolidation Analysis. Global Journal of Management and Business Research, 12, 1-11.

Omarini, A. (2013). Multichannel Distribution in Banking: Customers Perspectives and theoretical Frameworks to Increase User Acceptance of a Multiplatform Banking Business. Banks and Bank Systems, 8, 80-89.

Orhan, E. (2016). Urban Spatial Structuring Following Disasters: Empirical Findings from Location Choices of Businesses in Adapazari, Turkey. Journal of Risk Research, 19, 964-982. https://doi.org/10.1080/13669877.2016.1143864

Osterlund, D., Wikström, S., \& Yakhlef, A. (2005). Channel Integration: An Organizational Perspective. International Journal of Financial Services Management, 1, 26-40. https://doi.org/10.1504/IJFSM.2005.007983

Pingel, J., Case Jr., C., Amer, B., Hornung III, R. A., \& Schmidt, A. H. (2012). World Marrow Donor Association Crisis Response, Business Continuity, and Disaster Recovery Guidelines. Biology of Blood and Marrow Transplantation, 18, 1785-1789. https://doi.org/10.1016/j.bbmt.2012.08.006

PWC (2019). Pricing Innovation in Banking: The Next Frontier. India: PWC.

RBZ (2020). Interventions in Response to the Financial Vulnerabilities Caused by the Co- 
vid-19 Pandemic.

https://www.rbz.co.zw/documents/press/March/Press-Statement-COVID-Measures--w ebsite.pdf

Reichheld, F. F., \& Schefter, P. (2000). E-Loyalty. Harvard Business Review, 78, 105-113.

Samraz, H., \& Bakhtiar, M. (2012). The Impact of Service Quality, Customer Satisfaction and Loyalty Programs on Customer's Loyalty: Evidence from Banking Sector of Pakistan. International Journal of Business and Social Science, 3, 200-209.

Sarel, D., \& Marmorstein, H. (2003). Marketing Online Banking Services: The Voice of the Customer. Journal of Financial Services Marketing, 8, 106-118.

https://doi.org/10.1057/palgrave.fsm.4770111

Sawalha, I. H. S. (2013). Organisational Performance and Business Continuity Management: A Theoretical Perspective and a Case Study. Journal of Business Continuity and Emergency Planning, 6, 360-373.

Sekhar, P. (2014). Secured Techno-Economic Growth of India: Unleashing Hidden Growth Potential. Delhi: Micro Media Marketing Pvt. Ltd.

Sivadass, E., \& Baker-Prewitt, J. L. (2000). An Examination of the Relationship between Service Quality, Customer Satisfaction, and Store Loyalty. International Journal of Retail and Distribution Management, 28, 73-82.

https://doi.org/10.1108/09590550010315223

Steinfield, C. (2002). Understanding Click and Mortar E-Commerce Approaches: A Conceptual Framework and Research Agenda. Journal of Interactive Advertising, 2, 1-10. https://doi.org/10.1080/15252019.2002.10722057

Sultan, F., \& Rohm, A. J. (2004). The Evolving Role of the Internet in Marketing Strategy: An Exploratory Study. Journal of Interactive Marketing, 18, 6-19. https://doi.org/10.1002/dir.20003

U.S. Government (2007). Pandemic Influenza Preparedness in the Financial Services Sector. Washington, DC: U.S. Government Printing Office.

Wang, R., Nan, G., Chen, L., \& Li, M. (2020). Channel Integration Choices and Pricing Strategies for Competing Dual-Channel Retailers. IEEE Transactions on Engineering Management, 1-15. https://doi.org/10.1109/TEM.2020.3007347

Wirl, F. (2018). Agency Model and Wholesale Pricing: Apple versus Amazon in the E-Book Market. International Journal of the Economics of Business, 25, 243-264. https://doi.org/10.1080/13571516.2017.1401282

Wruuck, P. (2013). Pricing in Retail Banking: Scope for Boosting Customer Satisfaction and Profitability. Deutsche Bank Research, 1-25. http://www.dbresearch.com

Wuebker, G., Baumgarten, J., Schimdt-Gallas, D., \& Koderisch, M. (2008) Price Management in Financial Services: Smart Strategies for Growth. Gower Publishing, England.

Zhang, Y., Li, J., \& Xu, B. (2020). Designing Buy-Online-and-Pick-Up-in-Store (BOPS) Contract of Dual-Channel Low-Carbon Supply Chain Considering Consumers' Low-Carbon Preference. Mathematical Problems in Engineering, 2020, Article ID 7476019. https://doi.org/10.1155/2020/7476019 